\title{
Empirical Analysis of the Influence Factors of China's Current Account Surplus
}

\author{
Siyuan Hou ${ }^{1, a, *}$, Yipeng $\mathrm{Li}^{1, \mathrm{~b}}$ \\ ${ }^{1}$ Financial and Monetary Institute, Shanxi University of Finance and Economics, wucheng road, \\ Taiyuan, China \\ ${ }^{2}$ Financial and Monetary Institute, Shanxi University of Finance and Economics, wucheng road, \\ Taiyuan, China \\ a215109223@qq.com, b378650169@qq.com
}

Keywords: Current Balance, Current Account Balance, Factor Analysis

\begin{abstract}
The non-equalizing of the current balance has become a prominent problem in the operation of the world economy. The disequilibrium of current account balance has caused many negative effects on China's economy. In this paper, firstly, by analyzing the current account surplus from 1994 to 2016, choosing the balance of trade, foreign directly investment, gross domestic product to be the four factors which may have some relationships with the current account balance. And then through the factor analysis, multiple regression mode and corrected model get the conclusion that the balance of trade and foreign directly investment are two main factors, finally, put forward suggestions and countermeasures for our analysis.
\end{abstract}

\section{Trend and Analysis of the Current Account Balance}

The current account includes all debit and credit items that are exports and imports of goods and services, income receipts and income payments, and gifts [1]. Although that the current account is not the all of the balance of the payments, current account is used by lots of countries because it can reflect the overall import and export of one country and the power of competitive of the Primary Industry and the Secondary Industry. In this paper, we will analyze the data from the year of 1982 to 2016.

Table 1 Current account balance of China from 1982 to 2016

Units: billion dollars

\begin{tabular}{|c|c|c|c|c|c|}
\hline Years & $\begin{array}{c}\text { Current account } \\
\text { balance }\end{array}$ & Years & $\begin{array}{c}\text { Current account } \\
\text { balance }\end{array}$ & Years & $\begin{array}{c}\text { Current account } \\
\text { balance }\end{array}$ \\
\hline 1982 & 57 & 1994 & 77 & 2006 & 2318 \\
\hline 1983 & 42 & 1995 & 16 & 2007 & 3532 \\
\hline 1984 & 20 & 1996 & 72 & 2008 & 4206 \\
\hline 1985 & -114 & 1997 & 370 & 2009 & 2433 \\
\hline 1986 & -70 & 1998 & 315 & 2010 & 2378 \\
\hline 1987 & 3 & 1999 & 211 & 2011 & 1361 \\
\hline 1988 & -38 & 2000 & 204 & 2012 & 2154 \\
\hline 1989 & -43 & 2001 & 174 & 2013 & 1482 \\
\hline 1990 & 120 & 2002 & 354 & 2014 & 2360 \\
\hline 1991 & 133 & 2003 & 431 & 2015 & 3042 \\
\hline 1992 & 64 & 2004 & 689 & 2016 & 1964 \\
\hline 1993 & -119 & 2005 & 1324 & & \\
\hline
\end{tabular}

Date source: State Administration of Foreign Exchange

From the Table 1 that we can see, current account deficit exist in the year of the 1985, 1986, 1988, 1989 and 1993, the other thirty years China all has the favorable of current account, and then we use the EXCEL to draw a trend chart for our analysis. 


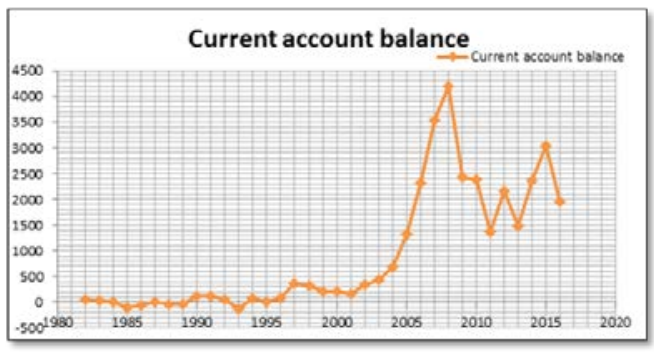

Fig. 1 The trend of the Current account balance

From the Table 1 and the Figure 1, we can make hypothesis in the sight of the reality. Firstly, from the year of 1982 to 1984, because of the implementation of the Reform and opening-up policy in China which lead to the advanced technology and products were needed eagerly in China, the current account balance always be a small deficit [2]. Secondly, the current account balance always overall deficit from the year of 1985 to 1989 which means that the high-speed growth of imports is the features in this period [3]. Thirdly, the implementation of import incentive policies mobilized the enthusiasm of foreign trade enterprises which stimulated the development of export trade from the year 1990 to 2000, the current account is in deficit only in the year of the 1993.Last but not least, from the year of 2001 to 2008, the current account surplus grew rapidly without any deficit, in the year of 2008, the international politics and economy were in an unstable state because of world crisis which made the surplus scale in China increasing accompanied with the bold growth rate dropped. And from the year of 2009 to 2016, China's current account was in surplus but it always in a fluctuating state.

\section{Analysis of the Factors Affecting the Current Account Surplus of China's International Balance of Payments}

\subsection{Balance of Trade}

The trade balance is the difference between the commodity exports and imports of a country during a given periods, it plays an important role in assessing the balance of payments not only because the imports and exports of commodities can reflect the state of the product quality, the industrial structure and the labor productivity, it also reflects the international competitiveness of the country [4].

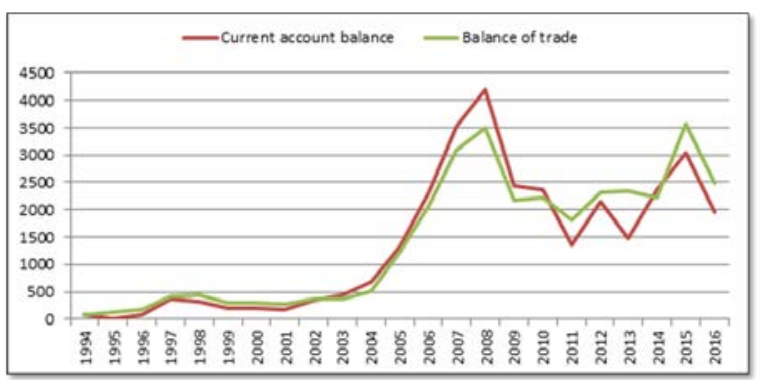

Fig.2 Current account balance and Balance of trade

Figure 2 shows the changing trend of Current account balance and the Balance of trade, from the figure that we can get the following conclusions. Firstly, current account balance and balance of trade have the same trend of change. Secondly, from the year of 1994 to 2003, the current account and balance of trade are always surplus but the variance of the surplus is not subject to change. Thirdly, after the year of 2003, the surplus of the current account balance and balance of trade growth at an extremely high speed [5]. Until the year of 2008, the Current account balance always greater than the Balance of trade, it not only because the commodities exported by our country are very competitive in the world market, but also the form of international transaction in our country is developing continuously. 


\subsection{Foreign Direct Investment}

Foreign direct investment has mainly affect the Current account balance from two aspects, and foreign direct investment has direct and indirect effects on our country. The direct effects refer to the influence of the imports and exports of foreign enterprise itself on the total trade volume, export, import and net export of the China, the indirect effects refer to the increased competition in the Chinese market after the entry of foreign investment, which forces Chinese enterprises to expand their products.

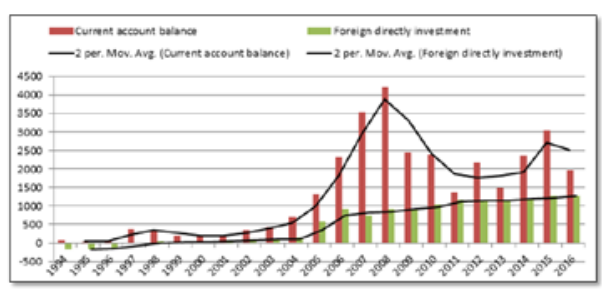

Fig.3 Current account balance and Foreign directly investment

\subsection{Other Factors}

Except the factors of balance of trade and foreign directly investment, the gross domestic product, consumer price index, the investment of residents' investment and saving, real interest rate and nominal interest rate also have some direct and indirect relationships to the current account balance.

\section{Empirical Analysis}

\subsection{Empirical Analysis Flow Chart}

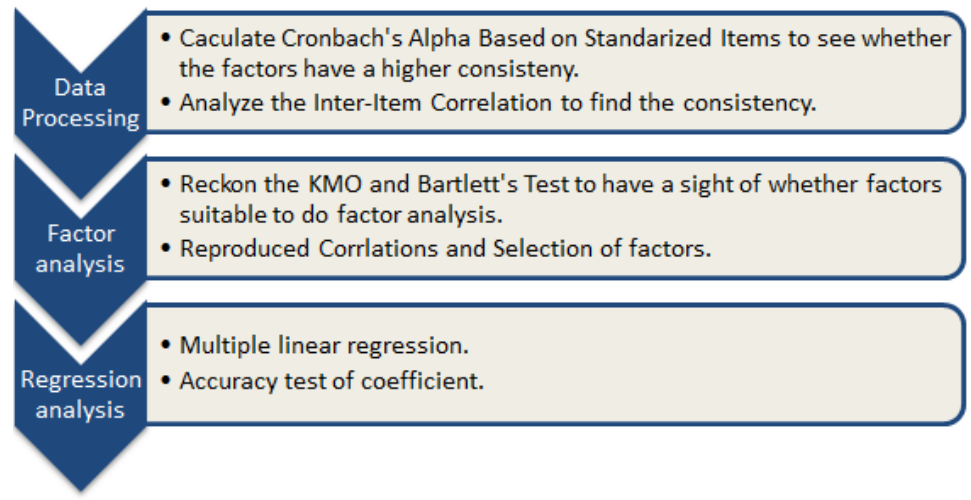

\subsection{Data Processing}

According to the Analysis of the factors, choose the balance of trade, foreign direct investment, gross domestic product and consumer price index these four factors to do Empirical analysis. And in the next analysis, we will use abbreviations in the Table 2 to replace these factors. This paper uses the data form the year of 1994 to 2016 to analyze the relationship not only between the independent and dependent variables, but also the relationships between each factor. The data mainly come from State Administration of Foreign Exchange and The China Financial Information Network.

Table 2 Factors and Abbreviations

\begin{tabular}{|cc|}
\hline Factors & Abbreviations \\
\hline Current account balance & CAB \\
\hline Balance of trade & BOT \\
\hline Foreign direct investment & FDI \\
\hline Gross domestic product & GDP \\
\hline Consumer price index & CPI \\
\hline
\end{tabular}


In order to carry out factor analysis, we first analyze the reliability of the data. After analyzing gets the conclusion that the Cronbach's Alpha Based on Standardized Item is 0.823 which means the five factors has the strong reliability.

\subsection{Factor Analysis}

Before the Factor analysis, we should have the KMO and Bartlett's Test to make sure whether the factors are suitable to have the factor analysis. From the KMO and Bartlett's Test, we can see that the Kaiser-Meyer Measure of Sampling Adequacy is 0.677, the Sig. is 0.000 . Because $0.677>0.5$ and $0.000>0.005$, the matrix of the rejection of the original hypothesis is identity matrix, that is, there is a correlation between the variables. This analysis shows that the factor analysis method is suitable for the question. Then use the SPSS 16.0 to draw the Scree Plot and Component Plot in Rotated Space to find out the main factors and use Reproduced Correlations Chart to determine definite variables.

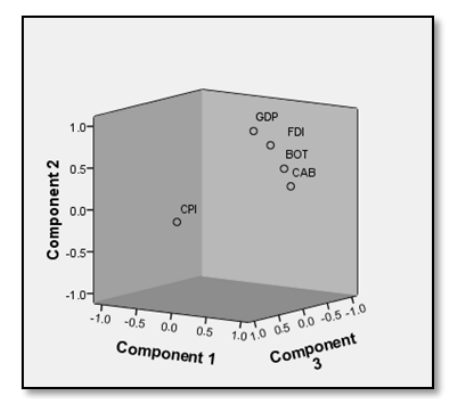

Fig.4 Component Plot in Rotated Space

From the Figure 4 get the conclusions. Firstly, there are two factors that are the main influencing factors of the whole model while the other two factors' influences are moderate. Secondly, if we want the CAB to be the dependent variable, FDI and BOT are closest to it, so they have the greatest possibility to influence the CAB. Next, based on the Reproduced Correlations, we can draw some further conclusions.

Table 3 Results of Reproduced Correlations

\begin{tabular}{|c|c|c|c|c|c|c|}
\hline \multicolumn{7}{|c|}{ Reproduced Correlations } \\
\hline & & ВOT & GDP & $\mathrm{CPI}$ & $C A B$ & FDI \\
\hline \multirow[t]{5}{*}{ Reproduced Correlation } & Вот & $1.000=$ & .802 & -.027 & .963 & .910 \\
\hline & GDP & .802 & $1.000^{\mathrm{a}}$ & -.093 & .652 & .926 \\
\hline & $\mathrm{CPI}$ & -.027 & -.093 & $1.000^{\mathrm{a}}$ & -.010 & -.115 \\
\hline & $\mathrm{CAB}$ & .963 & .652 & -.010 & $1.000^{3}$ & .816 \\
\hline & $\mathrm{FDI}$ & .910 & .926 & -.115 & .816 & $1.000^{3}$ \\
\hline \multirow[t]{5}{*}{ Residual } & ВOT & & $-1.332 E-15$ & $-1.676 \mathrm{E}-15$ & $-2.665 \mathrm{E}-15$ & $-1.776 \mathrm{E}-15$ \\
\hline & GDP & $-1.332 E-15$ & & $-5.135 E-16$ & $-1.443 E-15$ & $6.661 \mathrm{E}-16$ \\
\hline & CPI & $-1.676 \mathrm{E}-15$ & $-5.135 E-16$ & & $-1.481 \mathrm{E}-15$ & $-7.910 \mathrm{E}-16$ \\
\hline & $\mathrm{CAB}$ & $-2.665 E-15$ & $-1.443 E-15$ & $-1.481 \mathrm{E}-15$ & & $3.331 \mathrm{E}-16$ \\
\hline & FDI & $-1.776 \mathrm{E}-15$ & $6.661 \mathrm{E}-16$ & $-7.910 \mathrm{E}-16$ & $3.331 \mathrm{E}-16$ & \\
\hline
\end{tabular}

According to the Table 3, BOT and FDI both have reproduced correlations which are very close to 1 which means they must be the most important factors when we have the multiple regression analysis, and the reproduced correlations between GDP and CAB is 0.625 , which is moderate, we can just think about it when we do the regression analysis. The absolute value of the reproduced correlations of the CPI is just only 0.010, so we should get rid of it when we do the multiple regression analysis.

\subsection{Multiple Regression Analysis}

After the regressing got the equation as the following:

$$
\log (\mathrm{CAB})=-0.392069+1.001357 \log (\mathrm{BOT})+0.050907 \log (\mathrm{FDI})
$$

Firstly, $\mathrm{R}^{\wedge} 2$ of this equation is 0.953127 , which means this model is splendid fitted. Secondly, the T-statistic of the BOT and FDI are 5.053634 and 0.393386 which means the effect of BOT on CAB is 
greater than that of FDI. And the P-value of the BOT is only 0.0001 which is a very a very small value, and the P-value of the FDI is 0.6992, which means that the result is not very good. Thirdly, the BOT and FDI are positively correlated to CAT which means a separate increase in BOT or FDI will both increase the CAT's value. Last but not least, because there are many other factors that may interfere with the equation as GDP, the nominal interest rate and so on, we use a constant C_other to express the influence of other factors. And the revised equation is:

$$
\log (\mathrm{CAB})=-0.392069+1.001357 \log (\mathrm{BOT})+0.050907 \log (\mathrm{FDI})+\mathrm{C} \_ \text {other }
$$

In the coefficient of $\mathrm{C} \_$other, the interaction between all the factors leads to a zero interaction.

\section{Conclusions}

Since the sharp fluctuations in the current accounts can cause a severe economic reaction, the government should pay attention to the movements of the current account and adjust the different factors that may cause the fluctuations.

For the balance of trade, firstly, expand the trade level of the convenience, easy the part import management measures, and reduce the expenses and costs of import. Secondly, adjusting and optimizing the import structure, reduce tariffs, optimize the structure of tariff [6]. Finally, continuously improve the system of import, organize the recommendation of the commodities which can build a platform for the expansion of import.

The continuous growth of Foreign Directly Investment in China brings advanced technology to China and provides more employment channels and play an important role in the national economic development. We should perfect the introduction of foreign investment policy and improve the quality and level of the utilization of the foreign capital, so as to make the transition from quantity to quality, for example, to guide our orientation in foreign investment more high-end manufacturing and new technology, the modern service industry, the industry of environmental protection, and etc.

\section{References}

[1] Thomas A. Pugel International Finance. Renmin University of China press, 2016.11

[2] Sercu, Piet and Vanhulle, Cynthia, 1992, "Exchange Rate Volatility, International Trade, and the Value of Exploring Firms”, Journal of Banking and Finance.

[3] Nan Zhang, International capital circulation and China's foreign capital flow, International Financial Research, 2004(3)

[4] Mann, Catherine L, 1999, “Is The US trade Deficit sustainable?”, International Economics, Washington.

[5] Taylor, A.M.,2002, “ A Century of Current Account Dynamics”, NBER Working Paper, No.8927.

[6] Wilson, Peter and Tat, Kua Choon, 2001, "Exchange rates and the trade balance: the case of Singapore 1970 to 1996”, Journal of Asian Economics. 